


\section{Groundwater quality in selected caves in Ravni kotari (Croatia)}

\section{Kakvoća podzemne vode $\mathrm{u}$ odabranim spiljama u Ravnim kotarima (Hrvatska)}

Complex mechanisms of pollution transport in karst underground and the fact that contaminated cave water can be a health hazard if used for human consumption, imposes the need for monitoring the cave water quality. In order to determine groundwater quality, water samples were collected in four caves in Ravni kotari (Croatia) and analyzed for microbiological and chemical indicators of pollution. Microbiological analyses showed increased concentration of various coliform bacteria at all four locations. Probable sources of pollution are inadequately built septic tanks in nearby villages and bat guano in caves with bat colonies. Chemical analyses indicated values of possible pollutants to be much lower than the permitted values, which reflects the fact that agriculture, as a frequent source of chemical pollution in rural regions, is not as developed as it used to be, thus posing no serious threat to the groundwater quality.

Key words: groundwater quality, karst hydrogeology, bacterial contamination, chemical properties, Ravni kotari, Croatia
Složeni mehanizam transporta zagađenja u krškom podzemlju, kao i činjenica da kontaminirana spiljska voda može predstavljati opasnost po zdravlje ljudi ukoliko se koristi u vodoopskrbi, nameće potrebu praćenja (monitoringa) stanja kakvoće spiljske vode. Na uzorcima vode iz četiri speleološka objekta u Ravnim kotarima provedene su analize mikrobioloških i kemijskih parametara radi utvrđivanja kakvoće podzemne vode. Mikrobiološkim analizama utvrđene su povišene koncentracije različitih koliformnih bakterija u sva četiri objekta. Vjerojatan izvor tog zagađenja su neadekvatno izgrađene septičke jame u obližnjim selima te izmet šišmiša (guano) u spiljama u kojima postoje njihove kolonije. Kemijske analize podzemne vode pokazale su da su vrijednosti potencijalnih onečiśćivala znatno ispod zakonski dopuštene granice što se može povezati s činjenicom da poljoprivreda, kao čest izvor kemijskog zagađenja u ruralnim područjima, nije više toliko razvijena da bi predstavljala ozbiljnu prijetnju za kvalitetu podzemnih voda.

Ključne riječi: kakvoća podzemnih voda, hidrogeologija krša, bakterijska kontaminacija, kemijska svojstva, Ravni kotari, Hrvatska 


\section{Introduction}

Due to its geological and geomorphic characteristics karst is distinguished by extreme heterogeneity that reflects on complex hydrological and hydrogeological settings. Mature (telogenetic) karst aquifer consists of fractured limestone with very low matrix porosity where the water flows mainly through the system of joints and bedding planes (Gabrovšek and Dreybrodt, 2011). According to ASTM (2002), karst aquifer is characterised by tertiary porosity (secondary porosity modified by dissolution). It is highly anisotropic and non-homogenous and the flow of water within it is often rapid and turbulent, and thus, Darcy's law cannot be applied to the karst aquifer. Recharge can vary from dispersed to point-recharge exhibiting moderate to extreme temporal head variations and water chemistry variations (ASTM, 2002).

As for the contamination processes, karst aquifers display different properties than aquifers with intergranular porosity (Worthington et al., 2000). The aforementioned hydrological settings allow the transport of significant quantities of various contaminants into the subsurface, which in turn can produce large variations in water quality over short time scales (White, 1988). Lower temperatures in cave environments slow down bacterial metabolism, which increases their life span and allows them to thrive in extreme conditions (Davis et al., 2005). Many caves support a highly specialized assemblage of organisms that might be threatened by changes in water quality due to their low population densities (Bidwell et al., 2010). Cave water pollution can also have substantial effects on humans if such water is used for drinking or if polluted caves are frequently visited, which leads to exposure of visitors to contamination during their stay in the cave.

On the other hand, caves serve as a "window" through which the karst aquifers, widespread resources for public water supply, can be monitored (Klimchouk and Gudzenko, 1996). In general, everything from fertilizers, pesticides, metals, bacteria, petroleum hydrocarbons, and chlorinated solvents to exotic synthetic organic compounds and pharmaceuticals have been reported to contaminate cave waters (Lerch, 2011). Main sources of cave water pollutions are human activities which can cause disruption in the chemical balance of the groundwater or increase in the

\section{Uvod}

Izrazita heterogenost krša koja se odražava u složenim hidrološkim i hidrogeološkim značajkama posljedica je njegovih geoloških i geomorfoloških obilježja. Zreli (telogenetski) krški vodonosnik sastoji se od raspucanog vapnenca vrlo male poroznosti u kojem voda uglavnom cirkulira kroz sustave pukotina i slojnih ploha (Gabrovšek i Dreybrodt, 2011). Prema ASTM-u (2002), krški vodonosnik obilježava tercijarna poroznost, odnosno sekundarna poroznost modificirana otapanjem. Takav je vodonosnik izrazito anizotropan i nehomogen, često s brzim i turbulentnim protokom vode, te se na njega ne mogu primijeniti principi Darcyjeva zakona. Prihranjivanje takva vodonosnika može se kretati od disperznoga do točkastoga, a razina vode i njezin kemijski sastav podložni su umjerenim do ekstremnim varijacijama (ASTM, 2002).

Što se tiče kontaminacije, krški vodonosnici bitno se razlikuju od onih s međuzrnskom poroznošću (Worthington i dr., 2000). Zbog spomenutih hidroloških obilježja u krškim vodonosnicima moguć je transport znatnih količina zagađivača u podzemlje, što može uzrokovati velike promjene u kakvoći vode u kratkim razdobljima (White, 1988). Nadalje, snižena temperatura zraka u spiljama usporava metabolizam bakterija kojima se na taj način produljuje životni vijek, te im je omogućeno bujanje u ekstremnim uvjetima (Davis i dr., 2005). Mnoge su spilje staništa visoko specijaliziranim organizmima koji zbog male brojnosti mogu biti ugroženi promjenama kakvoće podzemne vode (Bidwell i dr., 2010). Onečišćenje vode u spiljama može imati znatan učinak i na zdravlje ljudi ako se takva voda upotrebljava u vodoopskrbi ili ako ljudi često posjećuju takve spilje te u njima dolaze u dodir sa zagađenom vodom.

S druge strane, spilje služe i kao svojevrstan „prozor" kroz koji se može promatrati krški vodonosnik kao važan dio vodoopskrbnog sustava (Klimchouk i Gudzenko, 1996). Općenito, u spiljskim su vodama zabilježene brojne vrste zagađivača, od gnojiva, pesticida, metala, bakterija, naftnih ugljikovodika i kloriranih otapala do egzotičnih sintetskih organskih spojeva i lijekova (Lerch, 2011). Naime, ljudske djelatnosti glavni su izvor zagađenja spiljskih voda, što može dovesti do poremećaja u kemijskom 
concentration of the microorganisms, particularly bacteria. The most frequent sources of contamination include waste dumping activities (point sources) or agricultural and farming activities (diffuse sources) which include possible contaminants such as nutrients added as fertilizers (especially sulphate, nitrogen, phosphorus and potassium), pesticides applied to the crops, and bacteria (Jimenez-Sanchez et al., 2008; Lerch, 2011).

Animal secretions can also be a source of bacterial contamination of the cave water. Many caves and pits in tropical and subtropical areas support large colonies of bats that form guano deposits on the cave floor, while these deposits usually contain many forms of coliform bacteria (e.g. Escherichia coli) (Campbell et al., 2011). Water in such caves is highly polluted and can cause serious health conditions in humans, either through consumption of such water or through contact of injured skin and water, which enables entrance of bacteria into blood. The study in Modrič Cave (30 $\mathrm{km} \mathrm{NE}$ of the town of Zadar) showed that the guano deposits are responsible for significantly elevated values of heavy metals $(\mathrm{Cu}, \mathrm{Cd}$ and $\mathrm{Zn})$ in both cave sediments and percolating water (Miko et al., 2002), and probably in the adjoining sea water (Surić et al., 2015). Humans can also bring bacteria into caves. Cave areas frequently traversed by humans contain more bacterial species than less-frequented areas (Northuop et al., 1997). Human influence could lead to increases in coliform bacteria concentration to the level considered as a threat to public health, and at the same time, also affect the natural bacterial assemblages (Campbell et al., 2011).

The main topic of this paper is the analysis of microbiological and chemical properties of the groundwater in two caves (Izvor Karišnice and Bijela voda) and two pits (Barina jama and Bonsai) in the Ravni kotari area, in order to determine groundwater quality and the sources of the cave water contamination. These caves were chosen because of the presence of water streams, the vicinity of settlements, and their accessibility. The main hypothesis was that the cave water at all locations must have been contaminated by microbiological and chemical pollutants, either from anthropogenic or natural sources. Water circulation in karst exhibits extreme seasonal variations so the quality of groundwater can significantly vary throughout the year. Frequent monitoring is particularly import- sastavu podzemne vode te do povećanja koncentracije mikroorganizama u vodi, posebice bakterija. Najčešći su izvori zagađenja odlagališta otpada (točkasti izvori) te poljoprivredne djelatnosti (raspršni/difuzni izvori) unutar kojih se kao potencijalni zagađivači ističu nutrijenti koji se upotrebljavaju kao gnojiva (posebice sulfati, dušik, fosfor i kalij), pesticidi koji se primjenjuju na usjevima te bakterije (Jimenez-Sanchez i dr., 2008; Lerch, 2011).

Životinjske izlučevine također mogu biti izvor zagađenja vode u spiljama, pa je tako u velikom broju spilja i jama u tropskim i suptropskim područjima moguće pronaći kolonije ššsmiša ispod kojih se nalaze naslage guana bogate brojnim oblicima koliformnih bakterija (npr. Escherichia coli) (Campbell i dr., 2011). U takvim spiljama voda je iznimno zagađena i može uzrokovati ozbiljne zdravstvene tegobe kod ljudi ako se upotrebljava za piće ili ako bakterije uđu u ljudski krvotok kroz površinske ozljede. Studija provedena u spilji Modrič (30 km SZ od Zadra) ukazala je na naslage guana kao izvor povišenih vrijednosti teških metala (bakra, kadmija i cinka) i u spiljskim sedimentima i u vodi prokapnici (Miko i dr., 2002), a vjerojatno i u obližnjemu moru (Surić i dr., 2015). Ljudi mogu i unijeti bakterije u spilje, pa dijelovi objekata u kojima ljudi često borave imaju više koncentracije bakterija od onih u koje ne zalaze (Northuop i dr., 1997). Č́ovjekov utjecaj može dovesti do povećanja koncentracije koliformnih bakterija do razine koja se smatra opasnom po ljudsko zdravlje, ali i po prirodnu bakteriološku ravnotežu u spiljama (Campbell i dr., 2011).

Glavni je cilj ovog rada analiza mikrobioloških i kemijskih svojstava podzemnih voda u dvije spilje (Izvor Karišnice i Bijela voda) i dvije jame (Barina jama i Bonsai) u Ravnim kotarima s namjerom utvrđivanja kakvoće podzemnih voda te izvora njihova zagađenja. Te spilje i jame odabrane su zbog postojanja vodenih tokova u njima, blizine naselja te pristupačnosti. Osnovna hipoteza bila je da bi u svim proučavanim objektima podzemna voda trebala biti kontaminirana mikrobiološkim i kemijskim polutantima bilo prirodnoga, bilo antropogenoga porijekla. Cirkulacija vode u kršu podložna je znatnim sezonskim promjenama, zbog čega se mijenja i kakvoća podzemnih voda tijekom godine. To nameće potrebu stalnog nadziranja (monitoringa),
R. Lončarić, M. Surić, D. Perica, K. Samodol, A. Deklić

Groundwater quality in selected caves in Ravni kotari (Croatia)

Kakvoća podzemne vode u odabranim spiljama u Ravnim kotarima (Hrvatska) 
HRVATSKI

GEOGRAFSKI

GLASNIK

77/2, 55-71 (2015) ant in assessment of concentration of contaminants with seasonal inputs and limited environmental persistence. Such data is necessary to determine the potential toxicity of contaminants in karst ecosystems (Lerch, 2011).

\section{Study area - geographical and geological settings}

The Ravni kotari area is a low karstic plateau surrounded by Velebit Mountain, the Bukovica highlands, Promina Mountain and the Adriatic Sea (Fig. 1). It consist of Mesozoic and Paleogene limestone, which forms the higher parts of the plateau, and $\mathrm{Pa}$ leogene flysch deposits in the lower parts (Fig. 2). Folds, normal and reverse faults, and overthrusts induced by subduction of the Adria (Apulia) microplate under the Eurasian plate, have produced a complex of geomorphic and geological settings, which are prerequisite for the development of diverse karst features in the Ravni kotari. From the hydrogeological point of view, the limestone is heavily karstified and permeable, while siliciclastic flysch deposits act as a hy- koje je nužno u procjeni koncentracije zagađivača sa sezonskim unosom i ograničenim trajanjem u okolišu, jer su takvi podaci ključni u određivanju potencijalne toksičnosti zagađivača u krškom ekosustavu (Lerch, 2011).

\section{Područje istraživanja - geografska i geološka obilježja}

Ravni kotari nizak su krški plato okružen Velebitom, Bukovicom, Prominom te Jadranskim morem (sl. 1). Viši dijelovi Ravnih kotara izgrađeni su uglavnom od mezozojskih i paleogenskih vapnenaca, dok u nižima prevladavaju paleogenske flišne naslage (sl. 2). Bore, rasjedi (normalni i reverzni) i navlake oblikovane subdukcijom jadranske (apulijske) mirkoploče pod euroazijsku ploču tvore geomorfološki i geološki kompleksno područje na kojem su se razvile raznolike krške pojave. S hidrogeološkog stajališta vapnenac u Ravnim kotarima izrazito je okršen i vodopropusan, dok siliciklastične naslage fliša djeluju kao hidrogeološke barijere. Klima je istraživanog područja submediteranska (Cfa

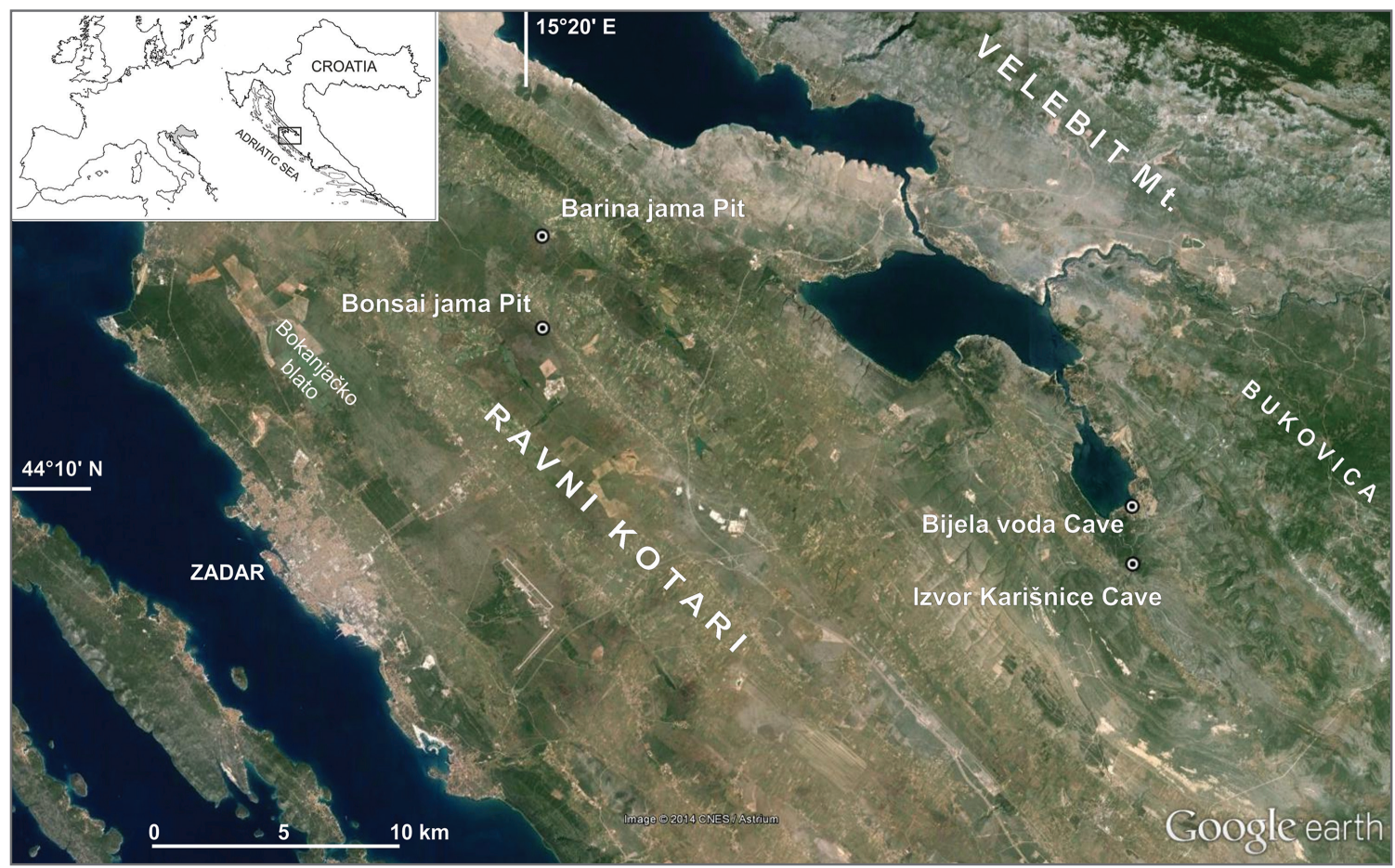

Fig. 1 Location of studied caves in Ravni kotari

Sl. 1. Lokacije istraživanih spilja u Ravnim kotarima 
drogeological barrier. The climate of the study area is sub-Mediterranean (Cfa according to Köppen), with average annual precipitation ranging from $900 \mathrm{~mm}$ to $1500 \mathrm{~mm}$ (Climate Atlas of Croatia, 2008). Summers are characterised by the lowest precipitation and the highest temperatures, and consequently with negative effective evapotranspiration. Thus, aquifer recharge is mostly restricted to the cold season, and such hydrological distribution strongly affects groundwater properties.

Ravni kotari is a relatively small drainage basin covering $380 \mathrm{sq} \mathrm{km}$ and it borders with catchment areas of three larger water recipients, Vransko jezero Lake, and the Zrmanja River and Krka River basins (Fritz, 1978). The groundwater origin is limited to the local precipitation immediately infiltrated through prevailing karstified limestones (Fritz, 1991). The appearance of the surface water in the form of springs and mainly seasonal streams is usually related to the contact zones between highly permeable carbonate rocks and less permeable flysch. Surface watercourses generally follow the geological and geomorphic structures of the Dinaric trend (NW-SE). Similarly, general outflow of groundwater is seaward, NW from the aquifer (Fig. 2). Besides that privileged direction, syphonal flows occur below the barriers perpendicularly to the direction of major structures (and barriers), through conduits extending below the present sea level (Fritz, 1991). Water emerges as the submarine groundwater discharge (diffuse and concentrate submarine outflow) and at numerous intermittent and permanent intertidal and coastal outlets. The most remarkable outlet in the western part is the freshwater Golubinka spring on the very coast, with maximum capacity of $1000 \mathrm{l} / \mathrm{s}$ $\left(\mathrm{Q}_{\min }=501 / \mathrm{s},\right)$ which is used for water supply. Along with it, springs and wells in Bokanjačko blato are also used for the water supply of the nearby city of Zadar. In the eastern part of Ravni kotari the most prominent surface flows are Bijela voda River and the seasonal stream Karišnica.

Ravni kotari is a sparsely populated area with an agricultural-based economy. However, in the recent past demographic and economic conditions have changed dramatically. Namely, during the Homeland War towns and villages in Ravni kotari suffered extensive damages, while most of its inhabitants were forced to leave their homes. Intensive agriculture, once a corner-stone of the local economy, was almost completely prema Köppenovoj klasifikaciji), s prosječnom godišnjom količinom oborina između 900 i $1500 \mathrm{~mm}$ (Klimatski atlas Hrvatske, 2008). Ljeta obilježavaju najniže količine oborina i najviše temperature te posljedično negativna efektivna evapotranspiracija. Zbog toga se vodonosnik prihranjuje uglavnom u hladnom dijelu godine, a takva hidrološka obilježja bitno utječu na svojstva podzemnih voda.

Sliv Ravnih kotara je razmjerno malo drenažno područje površine $380 \mathrm{~km}^{2}$ koje graniči sa slivovima triju većih recipijenata, Vranskog jezera, Krke i Zrmanje (Fritz, 1978). Porijeklo podzemne vode ograničeno je na lokalne oborine koje se vrlo brzo infiltriraju u prevladavajuće okršene vapnence (Fritz, 1991). Pojava površinskih voda u obliku izvora i uglavnom povremenih sezonskih tokova najčešće je povezana s kontaktnim zonama između izrazito vodopropusnih karbonatnih stijena i manje propusnog fliša. Površinski vodotoci pretežno slijede geološke i geomorfološke strukture dinarskog pravca pružanja (SZ - JI), a slično je i s podzemnom vodom koja otječe prema moru, sjeverozapadno od vodonosnika. Osim tog privilegiranog smjera otjecanja sifonalni tok vode odvija se ispod hidrogeoloških barijera poprečno na pravac pružanja glavnih struktura (i barijera) kroz kanale koji se protežu ispod današnje morske razine (Fritz, 1991). Ta voda izbija difuzno ili koncentrirano na podmorskim ispustima, kao i na brojnim periodičnim (intermitentnim) i stalnim intertajdalnim i priobalnim izvorima. Najznačajniji izvor vode u zapadnom dijelu Ravnih kotara jest izvor Golubinka, koji se nalazi na samoj obali mora $\mathrm{i}$ ima maksimalni kapacitet od $1000 \mathrm{1} / \mathrm{s}\left(\mathrm{Q}_{\min }=50\right.$ $1 / \mathrm{s}$ ) te se upotrebljava u vodoopskrbi. Uz njega se u vodoopskrbi obližnjeg Zadra upotrebljavaju i izvori i zdenci u Bokanjačkom blatu. U istočnom su dijelu Ravnih kotara glavni površinski tokovi rijeka Bijela voda (stalni tok) i Karišnica (povremeni tok).

Ravni kotari su rijetko naseljeno područje s gospodarstvom koje se temelji na poljoprivredi. No u nedavnoj prošlosti demografska i gospodarska obilježja tog prostora doživjela su značajne promjene. Naime, tijekom Domovinskog rata naselja u Ravnim kotarima pretrpjela su znatna razaranja, dok je stanovništvo uglavnom bilo protjerano iz svojih domova. Intenzivna poljoprivreda, nekada osnova lokalnoga gospodarskog razvoja, gotovo je potpuno napuštena. Posljednjih godina stanje se donekle po-
R. Lončarić, M. Surić, D. Perica, K. Samodol, A. Deklić

Groundwater quality in selected caves in Ravni kotari (Croatia)

Kakvoća podzemne vode u odabranim spiljama u Ravnim kotarima (Hrvatska) 
HRVATSKI

GEOGRAFSKI

GLASNIK

77/2,55-71 (2015.)

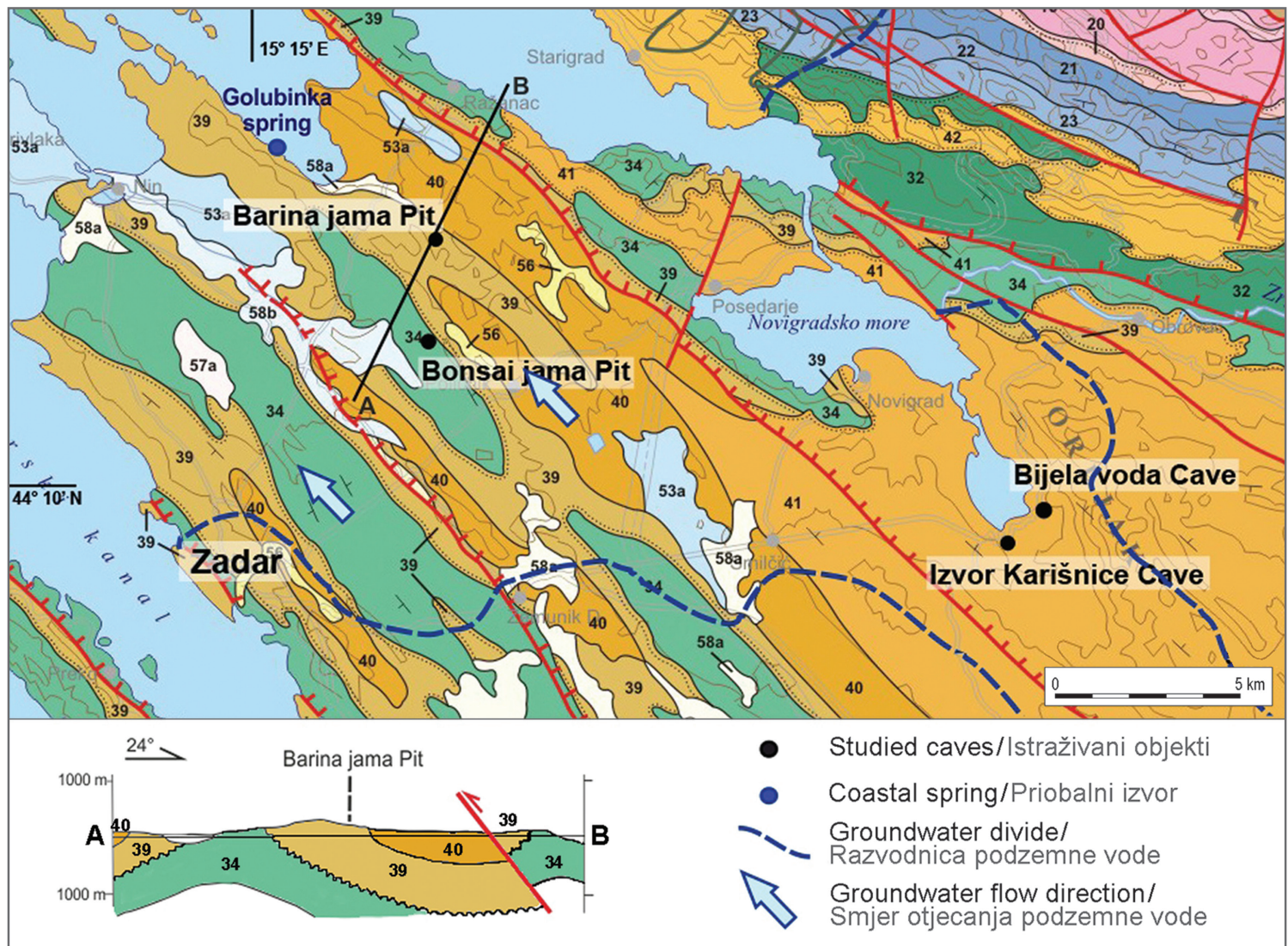

Fig. 2 Geological map of Ravni kotari with characteristic profile A-B (not to scale) and selected hydrogeological features: 34 - Upper Cretaceous rudist limestones (K2) - permeable; 39 - Foraminiferal limestones (E1,2) - permeable; 40 - Flysch (E,OI) - impermeable; 41 - Promina deposits $(E, O)$ - permeable (Geological Map of Croatia, 1:300 000, CGS, 2009; Hydrogeological Map of the Republic of Croatia, 1:600 000, IGR, 1997; Fritz, 1991).

SI. 2. Geološka karta Ravnih kotara s karakterističnim profilom A-B (nije u mjerilu) i odabranim hidrogeološkim pojavama; 34 - Gornjokredni rudistni vapnenci $\left(\mathrm{K}_{2}\right)$ - propusni; 39 - Foraminiferski vapnenci $\left(\mathrm{E}_{12}\right)$ - propusni; 40 - Fliš (E,Ol) - nepropusan; 41 - Prominske naslage (E,OI) - propusne (Geološka karta Republike Hrvatske, 1:300 000, HGI, 2009; Hidrogeološka karta Republike Hrvatske, IGI, 1997; Fritz, 1991.)

abandoned. In recent years the situation has somewhat improved, but agriculture is still far from its pre-war level. This fact is expected to have strong impact on groundwater quality since intensive agriculture is one of the leading sources of groundwater contamination.

All the studied caves are, in fact, "windows" into the aquifer relatively deeply karstified during the past sea-level low-stands. Their present position is partly in the epiphreatic zone with occasional floodings of different scale, while the lower portions are within the phreatic part of the aquifer.

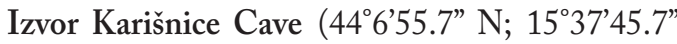
$\mathrm{E}$ ) is located in the eastern part of Ravni kotari, SE from the village of Donji Karin (Fig. 3). A seasonal stream (Karišnica) flows from the cave to the nearby Karinsko more Sea. The total length of the stream is pravilo, ali se poljoprivreda još nije vratila na prijeratnu razinu. Takvo stanje moglo bi snažno utjecati na kakvoću podzemne vode s obzirom na to da je intenzivna poljoprivreda jedan od njezinih glavnih zagađivača.

Sve istraživane spilje i jame su uzapravo „prozor" u vodonosnik koji je bio razmjerno duboko okršen tijekom nekadašnjih nižih morskih razina. Njegov današnji smještaj je dijelom u epifreatskoj zoni koja povremeno poplavljuje, dok su niži dijelovi dio freatske zone.

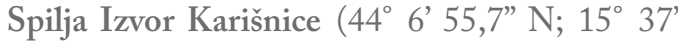
45,7” E) smještena je u istočnom dijelu Ravnih kotara, jugoistočno od sela Donji Karin (sl. 3). Povremeni vodotok (Karišnica) otječe iz spilje u obližnje Karinsko more, a njegova je ukupna duljina 
only $2400 \mathrm{~m}$. The cave entrance is $10 \mathrm{~m}$ in diameter, and the cave is approximately $120 \mathrm{~m}$ long and $20 \mathrm{~m}$ deep. It is a simple cave formed in Eocene-Oligocene Promina deposits (Fig. 3). Remains of water vegetation can be seen on the entire edge of the entrance indicating that the cave is occasionally completely svega $2400 \mathrm{~m}$. Promjer ulaza u spilju jest $10 \mathrm{~m}$, a spilja je duga oko $120 \mathrm{~m}$ i $20 \mathrm{~m}$ duboka. Riječ je o jednostavnom objektu nastalom u eocensko-oligocenskim Prominskim naslagama (s1. 3). Ostaci hidrofilne vegetacije vidljivi su na čitavome rubnom dijelu ulaza, što je pokazatelj da je spilja povreme-
R. Lončarić, M. Surić, D. Perica, K. Samodol, A. Deklić

Groundwater quality in selected caves in Ravni kotari (Croatia)

Kakvoća podzemne vode u odabranim spiljama u Ravnim kotarima (Hrvatska)
Fig. 3 Location and the outline of Izvor Karišnice Cave loutline authors: S. Božičević T. Dražina)

SI. 3. Lokacija i nacrt spilje u izvoru Karišnice lautori nacrta: S. Božičević, T. Dražina)

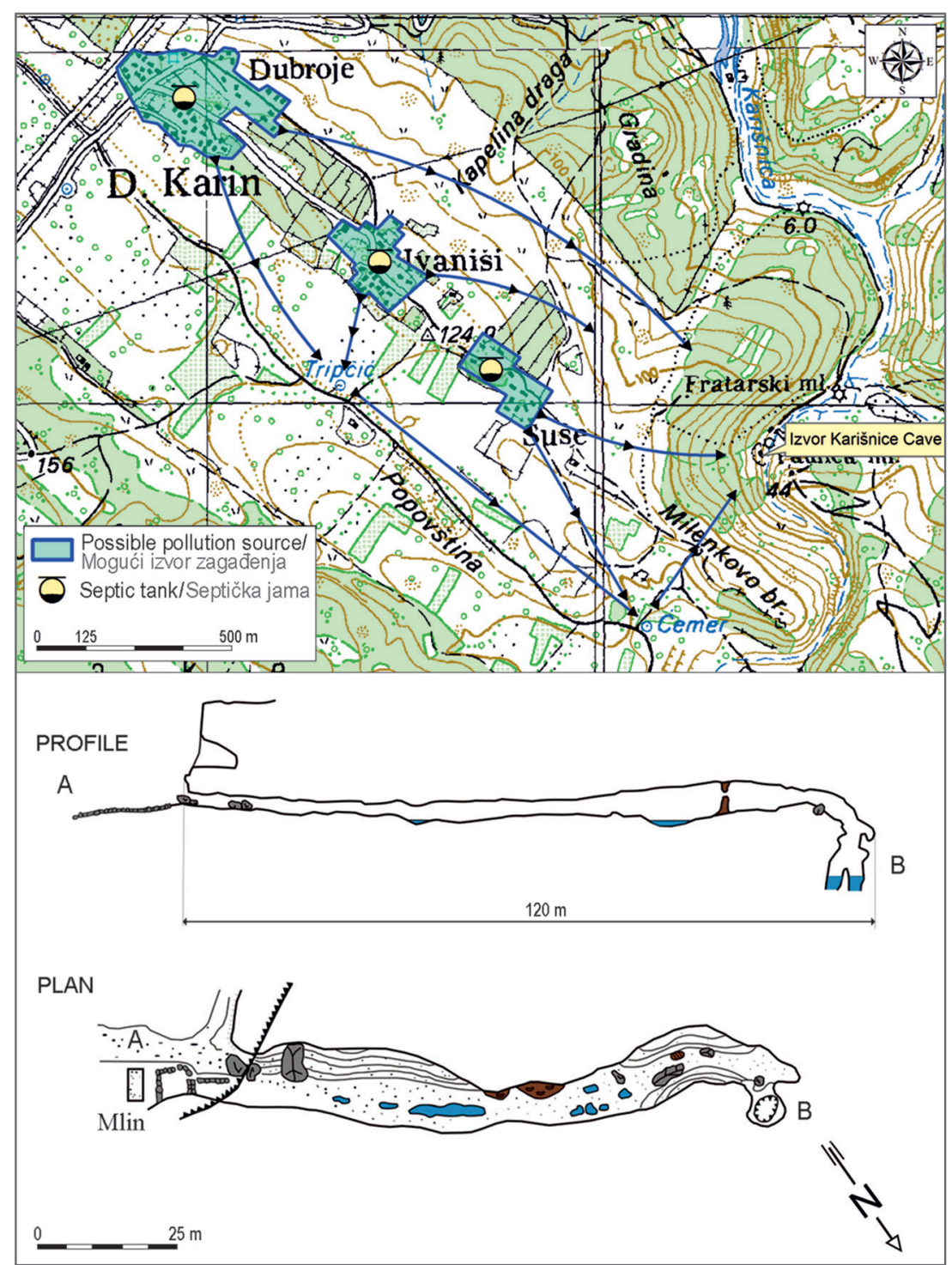

flooded. The first few meters of the cave have been paved with stone blocks, probably to provide the local population with easier access to the water during dry periods. Water is present in the cave throughout most of the year with significant seasonal variations in the water flow. no u potpunosti poplavljena. Prvih nekoliko metara spilje popločeno je kamenim blokovima, vjerojatno kako bi se lokalnom stanovništvu omogućio lakši pristup vodi u sušnim razdobljima. Voda je u spilji prisutna tijekom većeg dijela godine, sa znatnim sezonskim varijacijama protoka. 
HRVATSKI

GEOGRAFSKI

GLASNIK

77/2,55-71 (2015.)

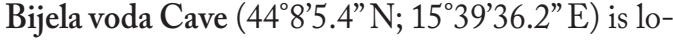
cated in the canyon of Bijela voda River, just a few kilometres NE from Izvor Karišnice Cave and is formed in Eocene-Oligocene Promina deposits as well (Fig. 4). The cave is $265 \mathrm{~m}$ long and ascends from the entrance towards the end, with roughly one third of the cave's floor under water (Fig. 4). The cave's main characteristic is a colony of bats, and there is an artificial pool inside the cave dammed by a concrete wall $(\mathrm{h}=0.5$ $\mathrm{m} ; \mathrm{w}=0.4 \mathrm{~m} ; \mathrm{l}=6 \mathrm{~m}$ ), which means that the cave water has been periodically used for local water supply.
Spilja Bijela voda $\left(44^{\circ} 8\right.$ ' 5,4”N; $\left.15^{\circ} 39^{\prime} 36,2^{\prime \prime} \mathrm{E}\right)$ nalazi se $\mathrm{u}$ kanjonu istoimene rijeke, svega nekoliko kilometara sjeveroistočno od spilje Izvor Karišnice i također je formirana u eocensko-oligocenskim Prominskim naslagama (sl. 4). Duga je $265 \mathrm{~m}$ i uzdiže se od ulaza prema kraju te je otprilike trećina spiljskog poda pod vodom. Osnovno je obilježje spilje kolonija šišmiša, a u unutrašnjosti postoji i umjetni bazen ograđen betonskim zidom visine 0,5 $\mathrm{m}$, širine $0,4 \mathrm{~m}$ i duljine $6 \mathrm{~m}$ jer se i ta spilja povremeno upotrebljavala za lokalnu vodoopskrbu.

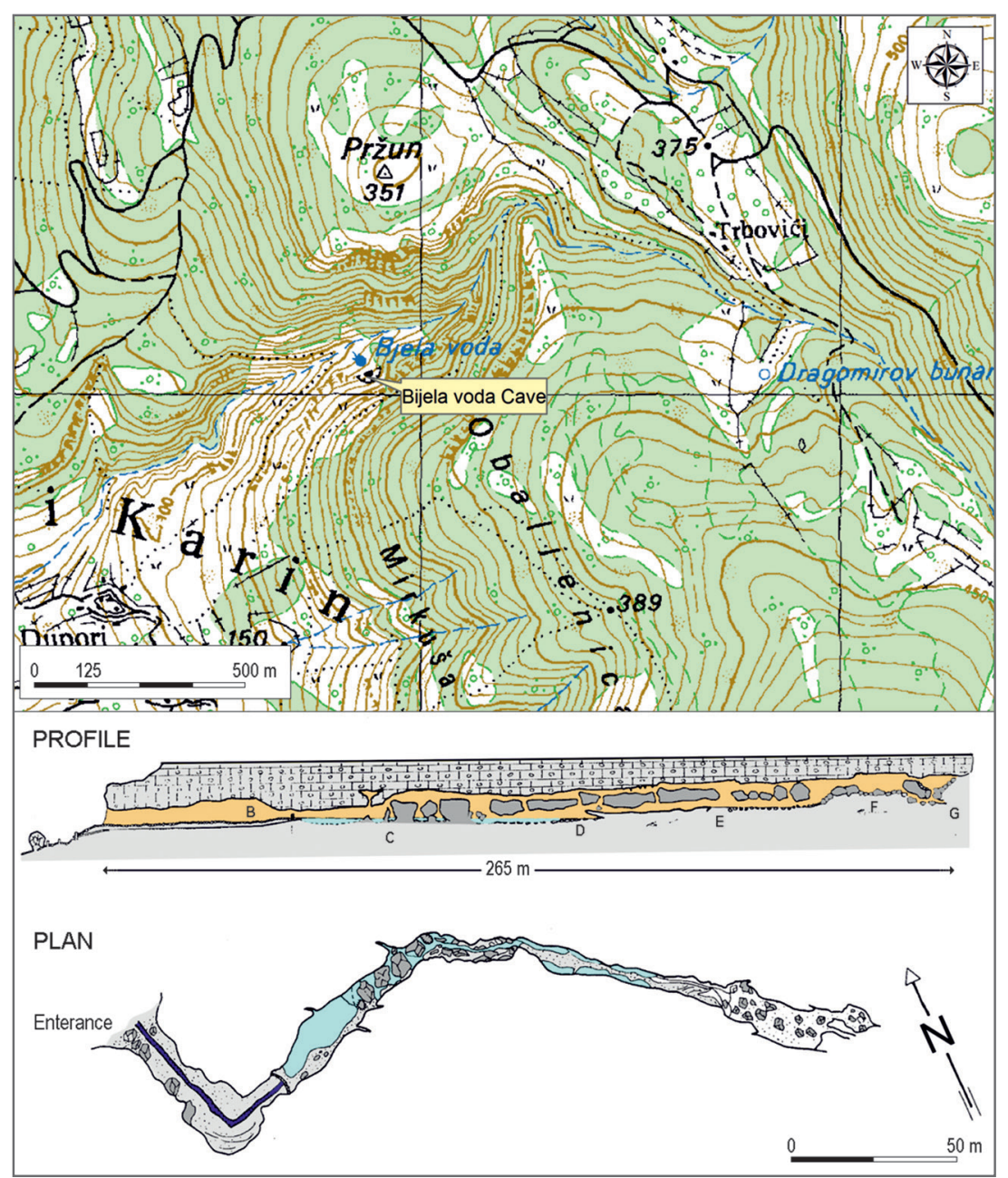

Fig. 4 Location and the outline of the Bijela voda Cave (author: S. Božičević)

SI. 4. Lokacija i nacrt spilje Bijela voda (autor: S. Božičević)
Barina jama Pit $\left(44^{\circ} 13^{\prime} 30.7^{\prime \prime} \mathrm{N} ; 5^{\circ} 21^{\prime} 7.5^{\prime \prime} \mathrm{E}\right)$ is located in the western part of Ravni kotari near the village of Marasovici (Radovin) (Fig 5). The pit is formed in Paleogene foraminiferal limestone and it is an object with simple morphology containing two vertical shafts,
Barina jama (44 $\left.14^{\prime} 30,7^{\prime \prime} \mathrm{N} ; 15^{\circ} 21^{\prime} 7,5^{\prime} \mathrm{E}\right)$ smještena je u zapadnom dijelu Ravnih kotara $u$ blizini sela Marasovići (Radovin). Jama je nastala u paleogenskim foraminiferskim vapnencima $i$ jednostavan je objekt s dva vertikalna okna dubo- 
$20 \mathrm{~m}$ and $16 \mathrm{~m}$ deep. It is about $45 \mathrm{~m}$ in total depth with a powerful stream on the bottom, which is in some places more than $2 \mathrm{~m}$ wide and about $0.5 \mathrm{~m}$ deep (Fig. 5). The stream belongs to the local catchment area of Golubinka coastal spring (Lončar, 2009). At the bottom of the pit there is a horizontal channel whose dimensions allow for further advancing in the future, and possible discovery of new passages or even connections with other caves in the vicinity. Biological researches has proved that the Barina jama Pit is home to an endemic species of freshwater shrimp (Troglocaris anophtalmus) and amphipod (Niphragus) (Lončar, 2009). These species are highly sensitive to any changes of water quality and could be threatened if the level of contamination remains increased over longer periods. At about half way through the pit, there is a large amount of guano from a bat colony, which probably has a negative impact on water quality at the bottom of the pit where the samples were taken. ka $20 \mathrm{~m}$ i $16 \mathrm{~m}$. Ukupna je dubina jame $45 \mathrm{~m}$, a na njezinu dnu nalazi se snažan vodotok koji je na mjestima širi od $2 \mathrm{~m}$ i dublji od $0,5 \mathrm{~m}$. Vodotok pripada slivu priobalnog izvora Golubinka (Lončar, 2009). Na dnu jame nalazi se horizontalni kanal čije dimenzije omogućuju napredovanje u budućim istraživanjima te potencijalno otkrivanje novih prolaza i mogućih spojeva s obližnjim spiljama. Biološka istraživanja potvrdila su da je Barina jama stanište endemskih vrsta slatkovodnih račića (Troglocaris anophtalmus) i amfipoda (Niphragus) (Lončar, 2009). Te su vrste iznimno osjetljive na promjene kakvoće vode i mogu biti ugrožene ukoliko dođe do trajnog zagađenja vode u jami. $\mathrm{Na}$ pola puta niz jamu nalazi se velika količina guana koja potječe od kolonije šišmiša i vjerojatno negativno utječe na kakvoću vode na dnu jame gdje su uzimani uzorci.

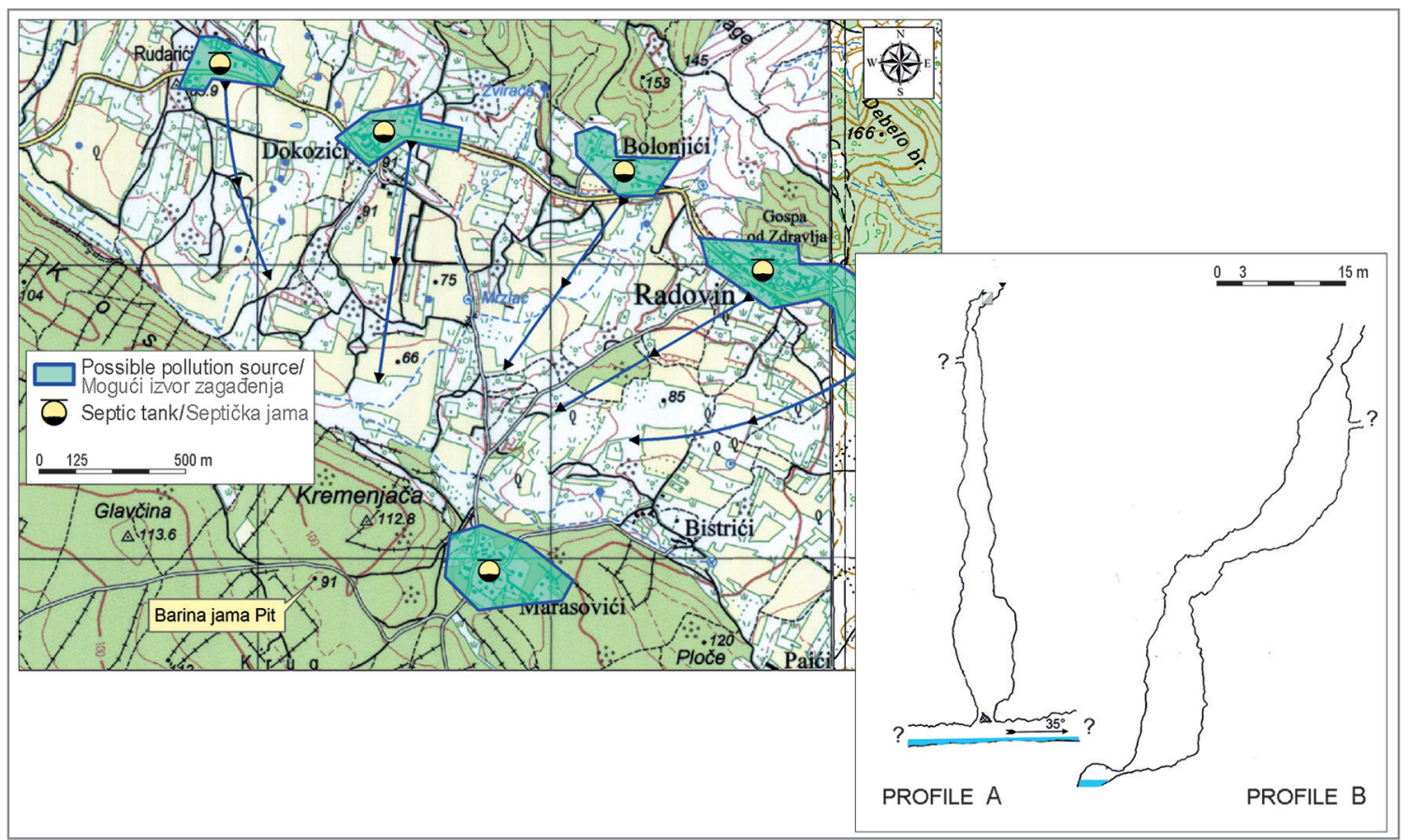

Fig. 5 Location and the outline of the Barina jama Pit (authors: P. Kurtin, M. Buzov, N. Šestić)

SI. 5. Lokacija i nacrt Barine jame (autori: P. Kurtin, M. Buzov, N. Šestić)

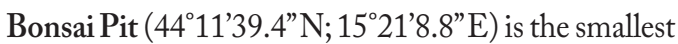
of the investigated caves and is only about $35 \mathrm{~m}$ deep. It is located $3.5 \mathrm{~km}$ south from Barina jama Pit and its lithological composition is dominated by the rudist limestone
R. Lončarić, M. Surić, D. Perica, K. Samodol, A. Deklić

Groundwater quality in selected caves in Ravni kotari (Croatia)

Kakvoća podzemne vode u odabranim spiljama u Ravnim kotarima (Hrvatska)

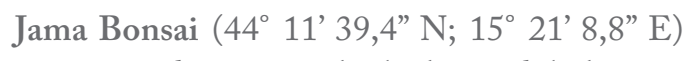
najmanja je od istraživanih objekata i duboka svega $35 \mathrm{~m}$. Nalazi se 3,5 km južno od Barine jame i u njezinu litološkom sastavu prevladavaju rudistni 


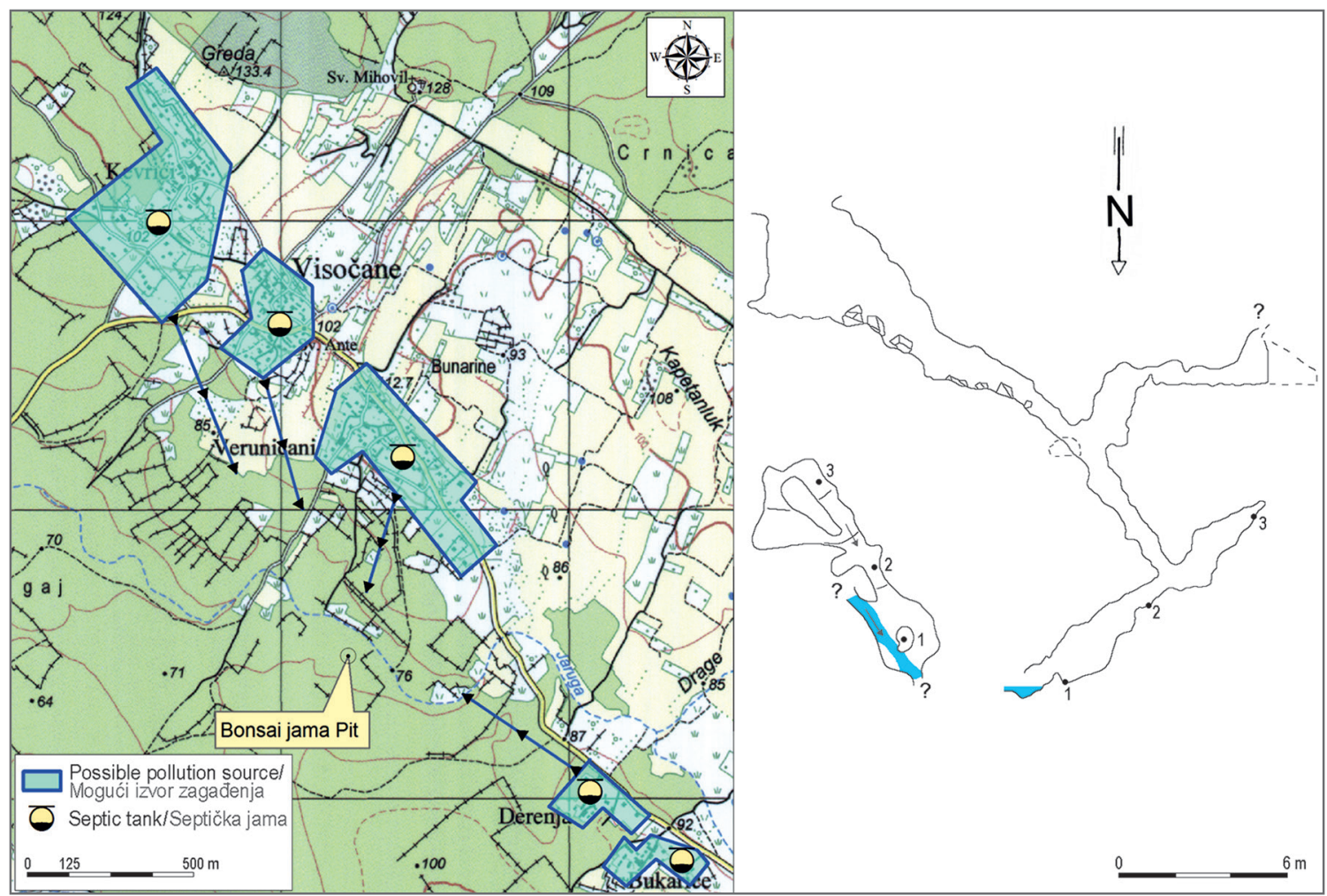

Fig. 6 Location and the outline of the Bonsai Pit (outline authors: T. Dražina, T. Marčić)

SI. 6. Lokacija i nacrt jame Bonsai (autori nacrta: T. Dražina, T. Marčić)

layers (Fig. 6). Bonsai Pit is rich in speleothems (stalactites, stalagmites, coralloids and draperies). The cave entrance is quite wide but it is covered with thick vegetation and therefore difficult to spot. On both sides of the pit there are several smaller passages (Fig. 6). Stagnant water is found at the bottom of the cave, and shrimp-like crustaceans have been observed (Lončar, 2009). At the time of the visit (in spring 2012) the surface of the water was covered with brown foam of unknown origin. Two other caves have been found in the vicinity of the Bonsai Pit which, together with Bonsai Pit, could be a part of larger cave system. Further research of the Bonsai Pit will be possible only with the use of cave-diving equipment.

\section{Sampling and analytical methods}

Water samples were collected during the spring of 2012. Bijela voda Cave hosts a large colony of bats, therefore sampling had to be conducted cautiously without disturbing the bat colony. Investigation and water sampling of the Bonsai Pit proved to be very vapnenci (sl. 6). Jama Bonsai bogata je stalaktitima, stalagmitima, koraloidima i spiljskim zavjesama. Ulaz u nju prilično je širok, ali se zbog guste vegetacije teško zamjećuje. $\mathrm{Na}$ obje njezine strane postoji nekoliko manjih prolaza (sl. 6). Stajaća voda nalazi se na dnu jame i u njoj su primijećeni slatkovodni račići (Lončar, 2009). Tijekom posjeta jami u proljeće 2012. površina vode bila je prekrivena smeđom pjenom nepoznata porijekla. U blizini jame Bonsai pronađene su još dvije spilje, koje bi s jamom Bonsai mogle biti dio većeg spiljskog sustava. Daljnja istraživanja te jame moguća su samo uz pomoć opreme za speleoronjenje.

\section{Uzorkovanje i metode analiza}

Uzorci vode uzimani su tijekom proljeća 2012. U spilji Bijela voda uzorkovanje je moralo biti iznimno oprezno zbog kolonije šišmiša, koji se ne smiju uznemirivati. Istraživanje i uzorkovanje u jami Bonsai bili su izazovni i opasni ne samo zbog toga 
challenging and dangerous. This pit is littered not only with household waste but also with numerous land mines and other explosive material disposed during or after the Homeland War. In addition, one of the safety issues is the high concentration of carbon-dioxide $\left(\mathrm{CO}_{2}\right)$, which is common in some caves in Ravni kotari (Lončar and Surić, 2011). Furthermore, passages within the caves and pits are prone to flash flooding, which also needs to be taken into consideration when collecting samples, especially during the wet season. Samples were collected in plastic containers that were stored in dark and cold containers and taken to the laboratory within 24 hours.

Microbiological and chemical analyses of the water samples were conducted in the Croatian National Institute of Public Health in Zadar. Analyzed microbiological indicators incorporate colony count by inoculation in a nutrient agar culture medium at $37^{\circ} \mathrm{C}$ (HRN EN ISO $6222 / 2000$ method) and the number of colonies at $22{ }^{\circ} \mathrm{C}$ (HRN EN ISO 6222/2000), detection and enumeration of Eshcerichia coli and coliform bacteria by membrane filtration (HR EN ISO 9308-1/2000), enumeration of Clostridium perfringens by membrane filtration, detection and enumeration of intestinal Enterococci by membrane filtration (HRN EN ISO 7899-2/2000), and presence of Pseudomonas aeruginosa (HR EN ISO 16266:2008) by membrane filtration.

Physico-chemical analyses included colour determination (HRN EN ISO 7887:2001, visual survey), quantitative turbidity measurement using an optical turbidimetar (HRN EN ISO 7027:2001*) and odour (HRN EN 1622:2002), measuring free residual chlorine by obtaining colorimetric method using N,N-diethyl-1,4-phenylen diamine (HRN EN ISO 7393-2:2001), determination of permanganate index by titration, ion chromatography measurement of ammonium concentration (HRN EN ISO 14911:2011), spectrophotometric measurement of nitrites using $\mathrm{N}$-(1-naphthyl)ethylenediamine dihydrochloride (SM (2005) 4500- $\mathrm{NO}_{2}{ }^{-*}$ ), ultra violet spectrophotometric screening of nitrates (SM (2005) 4500- $\mathrm{NO}_{3}{ }^{*}$ ), electrochemical water conductivity (HRN EN 27888:2008*), electrochemical hydrogen ions determination $(\mathrm{pH}$; HRN ISO 10523:2009*), and chlorides by silver nitrate titration with chromate indicator (Mohr's method) (HRN ISO 9297:1998). što je jama zatrpana kućnim otpadom nego i zato što su tijekom ili nakon Domovinskog rata u nju bačene mine i druga eksplozivna sredstva. Također, opasnost po sigurnost istraživača predstavlja i povećana razina ugljičnog dioksida, što je uobičajena pojava u nekim spiljama u Ravnim kotarima. Osim toga su u istraživanim objektima moguće i iznenadne poplave, što također treba uzeti u obzir kod uzimanja uzoraka, posebice u vlažnom dijelu godine. Uzorci vode skupljali su se u plastične spremnike, koji su pohranjeni na tamno mjesto prije nego što su odneseni u laboratorij unutar 24 sata od uzorkovanja.

Mikrobiološke i kemijske analize provedene su u Hrvatskom zavodu za javno zdravstvo u $\mathrm{Za}^{-}$ dru. Analizirani mikrobiološki pokazatelji uključili su brojenje kolonija inokulacijom na hranjivoj podlozi (agar) pri $37^{\circ} \mathrm{C}$ (metoda HRN EN ISO $6222 / 2000$ ) te brojenje kolonija pri $22{ }^{\circ} \mathrm{C}$ (HRN EN ISO 6222/2000). Membranskom filtracijom detektirana je i izbrojena Escherichia coli, zatim koliformne bakterije (HR EN ISO 9308-1/2000) i Clostridium perfringens, kao i crijevni enterokoki (HRN EN ISO 7899-2/2000) te se utvrđivala prisutnost bakterije Pseudomonas aeruginosa (HR EN ISO 16266:2008).

Fizikalne i kemijske analize obuhvatile su određivanje boje (HRN EN ISO 7887:2001, vizualni pregled), mutnoće pomoću optičkog turbidimetra (HRN EN ISO 7027:2001*) te mirisa (HRN EN 1622:2002). Izmjerena je i koncentracija slobodnoga rezidualnoga klora kolorimetrijskom metodom pomoću N,N-dietil-1,4-fenilendiamina (HRN EN ISO 7393-2:2001), titracijom je utvrđen permanganatni indeks, dok je ionskom kromatografijom izmjerena koncentracija amonijaka (HRN EN ISO 14911:2011). Spektrofotometrijom je određena koncentracija nitrita uz pomoć $\mathrm{N}$-(1-naftil)etilendiamin dihidroklorida (SM /2005/ 4500- $\mathrm{NO}_{2}{ }^{-*}$ ), a UV spektrofotometrijom izmjereni su nitrati (SM /2005/ 4500- $\left.\mathrm{NO}_{3}{ }^{*}\right)$. Utvrđena je i provodljivost vode (HRN EN 27888:2008*), njezina $\mathrm{pH}$ vrijednost (HRN ISO 10523:2009*) te koncentracija klorida uz pomoć titracije srebrnim nitratom s kromatskim indikatorom (Mohrova metoda) (HRN ISO 9297:1998).
R. Lončarić, M. Surić, D. Perica, K. Samodol, A. Deklić

Groundwater quality in selected caves in Ravni kotari (Croatia)

Kakvoća podzemne vode u odabranim spiljama u Ravnim kotarima (Hrvatska) 


\section{Results and discussion}

The results of microbiological analyses are presented in Tab 1. Microbiological analyses proved that the water at all four locations is contaminated with coliform bacteria. Escherichia coli, Pseudomonas aeruginosa and Enterococci bacteria have been confirmed in all water samples, while Clostridium perfringens was completely absent at all the locations. Faecal coliforms are generally considered as the most important indicators of fae-

\section{Rezultati i diskusija}

Rezultati mikrobiološke analize navedeni su u tab. 1. Mikrobiološkom analizom utvrđeno je da je voda u sva četiri istraživana speleološka objekta kontaminirana koliformnim bakterijama. Prisutnost Escherichije coli, Pseudomonas aeruginose i enterokoka potvrđena je u svim objektima, dok Clostridium perfringens nije pronađena ni u jednom uzorku. Fekalni koliformi općenito se smatraju

Tab. 1 Microbiological composition of groundwater samples

Tab. 1. Mikrobiološki sastav uzoraka podzemne vode

\begin{tabular}{|l|c|c|c|c|c|c|}
\hline \multicolumn{1}{|c|}{ Indicators } & Unit & $\begin{array}{c}\text { Permitted } \\
\text { values }\end{array}$ & $\begin{array}{c}\text { Izvor } \\
\text { Karišnice } \\
\text { Cave }\end{array}$ & $\begin{array}{c}\text { Bijela voda } \\
\text { Cave }\end{array}$ & $\begin{array}{c}\text { Barina jama } \\
\text { Pit }\end{array}$ & $\begin{array}{c}\text { Bonsai } \\
\text { jama Pit }\end{array}$ \\
\hline Jedinica & $\begin{array}{c}\text { Dopuštene } \\
\text { vrijednosti }\end{array}$ & $\begin{array}{c}\text { Spilja Izvor } \\
\text { Karišnice }\end{array}$ & $\begin{array}{c}\text { Spilja } \\
\text { Bijela voda }\end{array}$ & Barina jama & $\begin{array}{c}\text { Jama } \\
\text { Bonsai }\end{array}$ \\
\hline Number of colonies $\left(37^{\circ} \mathrm{C}\right)$ & $\mathrm{CFU} / \mathrm{ml}$ & $0-20$ & $\mathbf{8 0}$ & 20 & $\mathbf{4 0}$ & $\mathbf{7 3 0}$ \\
\hline Number of colonies $\left(22^{\circ} \mathrm{C}\right)$ & $\mathrm{CFU} / \mathrm{ml}$ & $0-100$ & 60 & 100 & $\mathbf{1 6 0}$ & $\mathbf{6 4 0}$ \\
\hline Total coliforms & $\mathrm{CFU} / 100 \mathrm{ml}$ & 0 & $\mathbf{1 4 0}$ & $\mathbf{4 0}$ & $\mathbf{1 6}$ & $\mathbf{1 6 0}$ \\
\hline Escherichia coli & $\mathrm{CFU} / 100 \mathrm{ml}$ & 0 & $\mathbf{2 4}$ & $\mathbf{8}$ & $\mathbf{2 4}$ & $\mathbf{1 2 0}$ \\
\hline Clostridium perfringens & $\mathrm{CFU} / 100 \mathrm{ml}$ & 0 & 0 & 0 & 0 & 0 \\
\hline Enteroccoci & $\mathrm{CFU} / 100 \mathrm{ml}$ & 0 & $\mathbf{8 0}$ & $\mathbf{1 0 0}$ & 0 & $\mathbf{4 6 0}$ \\
\hline Pseudomonas aeruginosa & $\mathrm{CFU} / 100 \mathrm{ml}$ & 0 & $\mathbf{4 0}$ & $\mathbf{2 0}$ & $\mathbf{1 6}$ & $\mathbf{5 0}$ \\
\hline
\end{tabular}

Note: Values in bold indicate concentration of bacteria above maximum permitted values

Napomena: vrijednosti označene masnim slovima prikazuju koncentraciju bakterija iznad zakonski propisanih vrijednosti

cal pollution in natural waters $(\mathrm{McF}$ Feters and Stuart, 1972; Clesceri et al., 1989). Although the absence of faecal coliforms does not imply that there are no other enteric pathogens present in the water, coliforms are chosen as the most reliable indicator of faecal bacterial pollution (Pasquarell and Boyer, 1995).

Izvor Karišnice Cave was thought to have water of high quality, suitable for human consumption. However, microbiological analysis disproved this assumption since it showed presence of coliform bacteria in amounts from $24 \mathrm{CFU}^{1 / 100} \mathrm{ml}$ for E. coli to 80 najvažnijim pokazateljima zagađenja vode u prirodi (McFeters i Stuart, 1972; Clesceri i dr., 1989). Iako nepostojanje fekalnih koliforma ne znači nužno da u vodi ne postoje drugi enterički patogeni, oni su odabrani kao najpouzdaniji pokazatelj zagađenja fekalnim bakterijama (Pasquarell i Boyer, 1995).

Za spilju Izvor Karišnice smatralo se da će imati visoku kakvoću vode, pogodnu za ljudsku uporabu. No mikrobiološka analiza opovrgnula je tu pretpostavku jer je pokazala koncentraciju koliformnih bakterija u rasponu od $24 \mathrm{CFU}^{1} / 100 \mathrm{ml}$ za E. coli

1 CFU - Colony Forming Unit. A measure of viable cells in which a colony represents an aggregate of cells derived from a single-progenitor cell. CFU is used to determine the number of viable bacterial cells in a sample per mL. Hence, it tells the degree of contamination in samples of water, vegetables, soil or fruits, or the magnitude of the infection in humans and animals (URL1).

1 CFU - Colony Forming Unit (jedinica formiranja kolonija bakterija), mjera kojom se utvrđuje broj bakterija sposobnih za život, gdje kolonija predstavlja skup stanica koje potječu od jedne progenitorske stanice. CFU služi za utvrđivanje broja bakterijskih stanica sposobnih za život u mililitru nekog uzorka. Prema tome, pokazuje stupanj kontaminacije uzorka vode, povrća, voća ili tla ili intenzitet infekcije kod ljudi i životinja (URL 1). 
CFU/100 ml for Enterococci (Tab. 1). The analyzed water is not compatible with the legal regulations for water quality and it should not be used for human consumption. But, since the values of bacteria are not high, the water could be purified. However, permanent purification is only possible if the source of contamination is clearly identified and removed. Based on the observation of the cave's surroundings, the most likely sources of bacteria are old septic tanks in three villages located about $1 \mathrm{~km}$ from the cave (Fig. 3). The tanks are inadequately built and are leaking sewage water in the catchment area of the cave. During the wet season contamination rapidly reaches cave water.

Water from Bijela voda Cave is used for human consumption and as such should have no signs of coliform contamination. Yet, results from samples taken about $50 \mathrm{~m}$ from the cave entrance indicated even higher values for Enterococci (100 CFU/ml) than in Izvor Karišnice Cave (Tab. 1). Contamination with other bacteria was less pronounced than in Izvor Karišnice Cave. Higher values of Enterococci bacteria are almost certainly caused by bat secretion. No other possible source of pollution was observed in or around the cave. There are no villages in the cave's close proximity, and the impact of settlements more distant from the cave cannot be determined without using the tracers.

Barina jama Pit was assumed to be polluted on the higher scale owing to the observed waste around the pit and in the first few metres of the cave channel (animal remains and a vehicle engine). However, microbiological analysis disproved the aforementioned assumptions. Water from Barina Jama Pit displayed the lowest level of bacteria with absolutely no signs of Enterococci (Tab. 1). Interestingly, during the speleological survey of the pit in 2003, water samples were also collected and analysis showed that the concentration of the total coliforms was also increased (42 CFU/100ml), but the rest of the bacterial indicators (number of colonies $\left(37^{\circ} \mathrm{C}\right)$ and faecal coliforms) were within the legal limits. A possible reason for the low level of bacterial contamination is the powerful water flow which does not allow for bacteria colonies to form. However, any pollution in this pit could cause serious habitat disturbance of the aforementioned endemic species.

The highest concentration of coliform bacteria was recorded in Bonsai jama Pit. For example, concentration of E. coli was five times higher than at Barina jama Pit and do 80 CFU za enterokoke (tab. 1). Analizirana voda nije u skladu sa zakonskim odredbama o kakvoći vode za piće, ali budući da vrijednosti nisu puno više od zakonom utvrđenog maksimuma, vodu je moguće pročistiti. Ipak, potpuno pročišćenje moguće je jedino ako se jasno odredi i ukloni izvor zagađenja. $\mathrm{Na}$ temelju istraživanja okolice spilje utvrđeno je da su najvjerojatniji uzrok zagađenja stare septičke jame u tri sela koja se nalaze oko $1 \mathrm{~km}$ od spilje (s1. 3). Septičke jame neadekvatno su izgrađene te propuštaju otpadne vode u podzemlje, pa u vlažnom dijelu godine zagađenje brzo dospije do vode u spilji.

Vodu iz spilje Bijela voda upotrebljavaju ljudi te stoga ne bi trebala biti zagađena koliformima. No rezultati analize uzoraka uzetih $50 \mathrm{~m}$ od ulaza u spilju pokazuju još veću koncentraciju enterokoka (100 CFU/100 ml) od onih u spilji Izvor Karišnice (tab. 1), dok je kontaminacija ostalim bakterijama bila slabije izražena. Povišena razina enterokoka gotovo je sigurno uzrokovana izlučevinama šišmiša, jer nijedan drugi mogući izvor zagađenja nije primijećen u spilji ili u njezinoj okolici. U blizini spilje nema naselja, a utjecaj naselja udaljenijih od nje nije moguće utvrditi bez bojenja vode.

Za vodu u Barinoj jami pretpostavljalo se da će biti zagađenija od vode u ostalim objektima zbog otpada u okolici jame i unutar njezinih prvih nekoliko metara (ostaci životinja i motornog vozila). No i ovdje je mikrobiološka analiza opovrgnula tu pretpostavku. Voda iz Barine jame imala je najnižu koncentraciju bakterija uz potpunu odsutnost enterokoka. Zanimljivo je napomenuti da su tijekom speleološkog istraživanja jame 2003. također prikupljeni uzorci vode u kojima je utvrđena povišena koncentracija koliformnih bakterija (42 CFU/100 $\mathrm{ml}$ ), ali su ostali pokazatelji bakterijskog zagađenja (broj kolonija pri $37{ }^{\circ} \mathrm{C}$ te koncentracija fekalnih koliforma) bili unutar zakonski propisanih vrijednosti. Mogući razlog niske koncentracije bakterija jest snažan tok vode u jami koji ne dozvoljava stvaranje kolonija bakterija. No bilo kakvo zagađenje jame moglo bi narušiti stanište endemskih vrsta spomenutih u prethodnim poglavljima.

Najviša koncentracija koliformnih bakterija zabilježena je u uzorcima vode iz jame Bonsai. Primjerice koncentracija $E$. coli bila je pet puta veća
R. Lončarić, M. Surić, D. Perica, K. Samodol, A. Deklić

Groundwater quality in selected caves in Ravni kotari (Croatia)

Kakvoća podzemne vode u odabranim spiljama u Ravnim kotarima (Hrvatska) 
HRVATSKI

GEOGRAFSKI

GLASNIK

77/2, 55-71 (2015.)

Tab. 2 Physical properties and chemical composition of groundwater samples

Tab. 2. Fizikalni parametri i kemijski sastav uzoraka podzemne vode

\begin{tabular}{|c|c|c|c|c|c|c|}
\hline Indicators & Unit & $\begin{array}{l}\text { Permitted } \\
\text { values }\end{array}$ & $\begin{array}{c}\text { Izvor } \\
\text { Karišnice } \\
\text { Cave }\end{array}$ & $\begin{array}{c}\text { Bijela } \\
\text { voda Cave }\end{array}$ & $\begin{array}{c}\text { Barina } \\
\text { jama Pit }\end{array}$ & $\begin{array}{l}\text { Bonsai } \\
\text { jama Pit }\end{array}$ \\
\hline Pokazatelji & Jedinica & $\begin{array}{l}\text { Dopuštene } \\
\text { vrijednosti }\end{array}$ & $\begin{array}{l}\text { Spilja Izvor } \\
\text { Karišnice }\end{array}$ & $\begin{array}{c}\text { Spilja } \\
\text { Bijela voda }\end{array}$ & Barina jama & $\underset{\text { Bonsai }}{\text { Jama }}$ \\
\hline Colour / Boja & & & none & none & none & none \\
\hline Turbidity / Zamućenost & NTU & $0-4$ & 0.3 & 0.3 & 0.3 & 0.4 \\
\hline Odou / Miris & & & none & none & none & none \\
\hline $\begin{array}{l}\text { Free residual chlorine / } \\
\text { Slobodni klor }\end{array}$ & $\mathrm{mg} / 1 \mathrm{Cl}_{2}$ & $0-0.5$ & 0 & 0 & 0 & 0 \\
\hline $\begin{array}{l}\text { Permanganate index / } \\
\text { Indeks permanganata }\end{array}$ & $\mathrm{mg} / 1 \mathrm{O}_{2}$ & $0-5$ & 0.7 & 0.7 & 1 & 1.1 \\
\hline Ammonium / Amonijak & $\mathrm{mg} / 1\left(\mathrm{NH}_{4}^{+}\right)$ & $0-0.5$ & $<0.05$ & $<0.05$ & $<0.05$ & $<0.05$ \\
\hline Nitrites / Nitriti & $\mathrm{mg} / 1\left(\mathrm{NO}_{2}^{-}\right)$ & $0-0.5$ & $<0.005$ & $<0.005$ & $<0.005$ & 0.006 \\
\hline Nitrates / Nitrati & $\mathrm{mg} / 1\left(\mathrm{NO}_{3}^{-}\right)$ & $0-50$ & 0.3 & 1 & 9.4 & 1.5 \\
\hline Conductivity / Vodljivost & $\mu \mathrm{Scm}^{-1}\left(20^{\circ} \mathrm{C}\right)$ & $0-2,500$ & 454 & 417 & 755 & 645 \\
\hline $\begin{array}{l}\text { Hydrogene ions / } \\
\text { Vodikovi ioni }\end{array}$ & $\mathrm{pH}\left(25^{\circ} \mathrm{C}\right)$ & $6.5-9.5$ & 7.2 & 7.5 & 7.5 & 7.1 \\
\hline Chlorides / Kloridi & $\mathrm{mg} / \mathrm{Cl}^{-}$ & $0-250$ & 8 & 8 & 22.1 & 20.5 \\
\hline
\end{tabular}

Izvor Karišnice Cave, and 15 times higher than in Bijela voda Cave. There are two obvious sources of contamination; one is organic and inorganic household waste within the cave and the other is again leaking septic tanks in the nearby villages, which are located on higher elevation than the pit (Fig. 5). Cave water is polluted on such a large scale that only thorough cleaning of the cave and its surroundings, together with preventing the waste water infiltrating the underground, could improve groundwater quality. Before any such attempt is made, explosive devices have to be removed from the cave.

The results of the physical and chemical analyses are shown in Tab. 2. Chemical analyses of the cave water showed rather surprising results. Namely, none of the water samples had any chemical constituents above legal limits for human consumption. Moreover, recorded values were in the lower portion of limit values. Slightly elevated conductivity values in the samples from Barina jama Pit and Bonsai jama Pit are probably due to contamination by organic and oxidizable inorganic matter, which coincides with a permanganate index nego u Barinoj jami, a čak petnaest puta veća nego u spilji Izvor Karišnice. Dva su očigledna izvora zagađenja; organski i anorganski kućanski otpad u jami te otpadna voda iz septičkih jama iz obližnjih sela koja se nalaze na većoj nadmorskoj visini od jame (s1.5). Voda u jami toliko je zagađena da njezinu kakvoću može poboljšati samo temeljito čišćenje jame i njezine okolice uz sprečavanje infiltracije otpadnih voda u podzemlje. No prije nego što se poduzmu takvi koraci, iz jame se moraju ukloniti eksplozivna sredstva.

Rezultati fizikalnih i kemijskih analiza navedeni su u tab. 2. Kemijska analiza vode pokazala je iznenađujuće rezultate. Naime u uzorcima vode nije zabilježen nijedan kemijski konstituent čija bi koncentracija bila iznad zakonski propisanih maksimalnih vrijednosti. Štoviše, zabilježene vrijednosti bile su izrazito niske. Blago povišena provodljivost u uzorcima iz Barine jame i jame Bonsai vjerojatno je uzrokovana kontaminacijom organskim i oksidiranim anorganskim tvarima, što se podudara s 
elevation. Sporadic use of organic fertilizers in the area and guano from the colony of bats found at the site may contribute to the higher permanganate index.

Chemical contamination is often associated with a higher concentration of bacteria, since both usually originate from the same pollution source. Agriculture can be responsible for occurrence of ammonium, nitrites, nitrates, heavy metals, organic solvents and petroleum products in the cave water (Lerch, 2011). Possible explanation for the lack of chemical contamination is the fact that intensive agriculture is virtually non-existent in the researched area. Constant monitoring of cave water quality is needed to determine whether the recorded values are constant, or there is a period of year when the concentration of chemicals rises.

\section{Conclusion}

Microbiological and chemical analysis of the cave water showed completely opposing results. While the microbiological indicators were mostly well above permitted values, chemical indicators showed no sign of contamination. It is evident that the higher levels of Enterococci bacteria at all four locations are at least partially influenced by humans, while other major sources of pollution are bat colonies. A high abundance of bacteria could be an ecosystem warning signal and coliform bacteria can also be a human health concern. Inadequately built septic tanks are thought to be the main source of pollution caused by humans. If such tanks are used over long periods of time, chances are that the waste water will find its way into the underground. Once underground, water can move rapidly through complex system of fissures or larger channels in karst, affecting groundwater kilometres away from the pollution source. This groundwater can become a health hazard if wells and springs are used without proper monitoring of water quality. Such problems frequently occur in other karst areas of Croatia, particularly on islands where septic tanks are also frequently used (Lončarić et al., 2011). Solutions to the problem can be either repair of the septic tanks or connection of the households to joint sewage systems. But these solutions are often expensive and thus hard to enforce in economically underdeveloped areas such as Ravni kotari. The lack of chemical pollution in the ground- povišenim permanganatskim indeksom. Sporadična uporaba organskih gnojiva u tom području te naslage guana kolonija šišmiša mogle bi biti uzrok povišenoga permanganatskog indeksa.

Kemijska kontaminacija često je povezana s povišenom koncentracijom bakterija jer obično obje potječu od istog izvora zagađenja. Poljoprivredna djelatnost može biti uzrok prisutnosti amonijaka, nitrita, nitrata, teških metala, organskih otapala i naftnih prerađevina u spiljskoj vodi (Lerch, 2011). Moguće objašnjenje za nepostojanje kemijskog zagađenja spiljske vode jest činjenica da intenzivna poljoprivreda praktično ne postoji u istraživanome području. Potreban je stalan monitoring kakvoće vode u spiljama radi utvrđivanja jesu li zabilježene vrijednosti stalne ili postoji razdoblje u godini kada koncentracija kemikalija u vodi raste.

\section{Zaključak}

Mikrobiološke i kemijske analize spiljske vode pokazale su suprotne rezultate. Dok su mikrobiološki pokazatelji bili podosta iznad dopuštenih vrijednosti, kemijski pokazatelji nisu upućivali na zagađenje vode. Očigledno je da je povišena razina enterokoka u svim objektima barem djelomično uzrokovana ljudskim aktivnostima, dok su drugi veliki izvor zagađenja kolonije šišmiša. Obilje bakterija u vodi može biti znak upozorenja za ekosustav, a koliformne bakterije mogu predstavljati i opasnost po zdravlje ljudi. Neodgovarajuće izgrađene septičke jame smatraju se glavnim izvorom antropogenog zagađenja, naročito ako se one upotrebljavaju tijekom duljeg razdoblja, jer time raste vjerojatnost infiltracije otpadnih voda u podzemlje. Kada takva voda prodre u podzemlje, brzo se kreće kroz složene sustave pukotina ili većih kanala, što utječe na podzemne vode kilometrima udaljene od izvora zagađenja. Zagađena podzemna voda može biti prijetnja zdravlju ljudi ako se zdenci i izvori upotrebljavaju bez odgovarajućeg nadzora kakvoće vode. Navedeni se problem učestalo javlja i u drugim krškim područjima Hrvatske, posebice na otocima, gdje se septičke jame često upotrebljavaju za zbrinjavanje otpadnih voda. Rješenje problema može biti ili popravak postojećih jama ili spajanje kućanstava na zajednički kanalizacijski sustav. No takva su rješenja često skupa i teško ih je provesti u gospodarski nera-
R. Lončarić, M. Surić, D. Perica, K. Samodol, A. Deklić

Groundwater quality in selected caves in Ravni kotari (Croatia)

Kakvoća podzemne vode u odabranim spiljama u Ravnim kotarima (Hrvatska) 
GEOGRAFSKI

GLASNIK

77/2, 55-71 (2015.)

\section{Acknowledgement} Zahvala

Literature

ASTM Subcommittee D-18-21, 2002 Standard guide for design of ground-water monitoring systems in karst and fractured-rock aquifers: West Conshohocken, Pa., American Society of Testing and Materials, Annual Book of ASTM Standards v. 04.08, ASTM D5717-95, p. 1421-1438.

Bidwell, J. R., Becker, C., Hensley, S., Stark, R., Mever, M. T., 2010: Occurrence of organic wastewater and other contaminants in cave streams in Northeastern Oklahoma and Northwestern Arkansas, Archives of Environmental Contamination and Toxicology 54, 286-298.

Campbell, J. W., Watson, A., Watson, C., Ball, H., Pirkle, R., 2011: Escherichia coli, other coliform, and environmental chemoheterothropic bacteria in isolated water pools from six caves in northern Alabama and northwestern Georgia, Journal of Cave and Karst Studies 73/2, 75-82.

Clesceri, L. S., Greenburg, A. E., Trussel, R. R., 1989: Standard methods for the examination of water and wastewater, 17th ed., American Public Health Association, Washington.

Davis, R. K., Hamilton, S., van Brahana, J., 2005: Escherichia coli survival in man- zvijenim područjima poput Ravnih kotara. Manjak kemijskog zagađenja podzemnih voda može se pripisati nedovoljno razvijenoj intenzivnoj poljoprivredi koja nije povratila svoje gospodarsko značenje od završetka rata 1995.

Zbog složenosti cirkulacije vode u kršu izvore zagađenja ponekad je teško utvrditi. Za bolje razumijevanje složenih mehanizama prenošenja zagađenja u podzemnoj vodi, provest ce se daljnja istraživanja koja su ključna za utvrđivanje osnovnog stanja. To će omogućiti procjenu učinaka budućih promjena u iskorištavanju zemljišta na kakvoću vode. Stalni monitoring pružit će i točniju procjenu koncentracije polutanata u vodonosniku.

Ovo istraživanje je financiralo Ministarstvo znanosti, obrazovanja i sporta Republike Hrvatske (znanstveni projekt 269-2693084-3083 Hrvatski priobalni krški prostor - geomorfološke i ekološke značajke). tled karst springs and streams, northwest Arkansas Ozarks, USA, Journal of the American Water Resources Association 41, 1279-1287.

Fritz, F., 1978: Hidrologija Ravnih kotara i Bukovice, Krš́ Jugoslavije 10/1,1-43.

Fritz, F., 1991: Utjecaj recentnog okršavanja na zahvaćanje voda, Geološki vjesnik 44, 281-289.

Gabrovšek, F., Dreybrodt, W., 2011: Spreading of tracer plumes through confined telogenetic karst aquifers: A model, Journal of Hydrology 409 (1-2), 20-29.

Jiménez-Sánchez, M., Stoll, H., Vadillo, I., Lopez-Chicano, M., Dominguez-Cuesta, M., Marin-Rosales, W., Meléndez-Asensio, M., 2008: Groundwater contamination in caves: four case studies in Spain, International Journal of Speleo$\log y 37 / 1,53-66$.

Klimatski atlas Hrvatske (Climate atlas of Croatia), Državni hidrometeorološki zavod, Zagreb, 2008.

Klimchouk, A. B., Gudzenko, V. V., 1996: Chernobyl radiocaesium in a karst system, Marble Cave, Crimea, Environmental Geology 28/2, 161-166.

Lerch R. N., 2011: Contaminant transport in two Central Missouri karst recharge areas, Journal of Cave and Karst Studies $73 / 2,99-113$

Lončar, A., 2009: Značajke speleoloških objekata u sjeverozapadnom dijelu Ravnib kotara, diplomski rad, Odjel za geografiju, Sveučilište u Zadru.

Lončar, A., Surić, M., 2011: Značajke speleoloških objekata u sjeverozapadnom dijelu Ravnih kotara, u: Zbornik radova 1. hrvatskog speleološkog kongresa (ur. Garašić, M.), u tisku.

Lončarić, R., Surić, M., Magaš, D., 2011: Influence of water availability on historical, demographical and economical development of the Kvarner islands (Croatia), Annales Series historia et sociologia 21/2, 425-436.

McFeters, G. A., Stuart, D. G., 1972: Survival of coliform bacteria in natural waters: Field and laboratory studies with membrane-filter chamber, Applied Microbio$\log y 24,805-811$.

Miko, S., Kuhta, M., Kapeli, S., 2002: Environmental baseline geochemistry of sediments and percolating waters in the Modrić cave, Croatia, Acta Carsologica 31/1, 135-149.

Northoup, D. E., Beck, K. M., Mallroy, L. M., 1997: Human impact on microbial com- 
munities of Lechuguilla cave: Is protection possible during active exploration?, abstract, National Speleology Society Convention Program, Sullivan Missouri, 55.

Pasquarell, G. C., Boyer, D. G., 1995: Herbicides in karst groundwater in southeast West Virginia, Journal of Environmental Quality 25, 755-765.
Surić, M., Lončarić, R., Buzjak, N., Schultz, S., Šangulin, J., Maldini, K., Tomas, D., 2015: Influence of submarine groundwater discharge on sea water properties in Rovanjska-Modrič karst region (Croatia), Environmental Earth Sciences, Volume 74, Issue 7, pp 5625-5638, doi.:10.1007/s12665-015-4577-2.

White, W. B., 1988: Geomorphology and hy- drology of karst terrains, Oxford University Press, New York.

Worthington, S. R. H., Davies, G. J., Ford, D. C., 2000: Matrix, fracture and channel components of storage and flow in a Paleozoic limestone aquifer, u: Groundwater flow and contaminant transport in carbonate aquifers (ur. Sasowsky, I. D., Wicks, C. M.), 113-128.

Biology online, http://www.biology-online.org/dictionary/Colony-forming_unit (8. prosinac 2014.)

Geological map of Croatia, 1:300 000, Croatian Geological Survey, 2009

Geološka karta Hrvatske, 1:300 000, Hrvatski geološki institut, 2009.

Sources

Izvori

Hydrogeological map of the Republic of Croatia, 1:600 000, Institute of Geological Research, 1997

Hidrogeološka karta Republike Hrvatske, 1:600 000, Institut za geološka istraživanja, 1997.

Robert Lončarić

rloncar@unizd.hr

Assistant Professor, University of Zadar, Department of Geography, Centre for Karst and Coastal Research, Ulica dr. Franje Tuđmana 24i, 23000 Zadar

Maša Surić

Associate Professor, University of Zadar, Department of Geography, Centre for Karst and Coastal Research

Dražen Perica

Associate Professor, University of Zadar, Department of Geography, Centre for Karst and Coastal Research

Krešimir Samodol

Speleological section Liburnija, Mountaineering society Paklenica

Andrea Deklić

Speleological section Liburnija, Mountaineering society Paklenica
R. Lončarić,

M. Surić,

D. Perica,

K. Samodol,

A. Deklić

Groundwater quality in selected

caves in Ravni

kotari (Croatia)

Kakvoća podzemne vode u odabranim spiljama u Ravnim kotarima (Hrvatska)
Authors

Autori 